\title{
The Development of Digital Competences for University Tourism Teachers
}

\author{
Derling José Mendoza Velazco \\ Escuela de Formación de Soldados del Ejército ESFORSE. \\ Universidad de las Fuerzas Armadas - ESPE. Ambato, Ecuador \\ http://orcid.org/0000-0001-8275-3687 \\ Magda Francisca Cejas Martínez \\ Universidad Nacional de Chimborazo UNACH, and \\ Universidad de las Fuerzas Armadas - ESPE. Riobamba, Ecuador \\ http://orcid.org/0000-0002-0618-3608 \\ Mercedes Navarro Cejas \\ Universidad Técnica de Manabí UTM, Manabí, Ecuador \\ http://orcid.org/0000-0003-4377-7250 \\ María Hipatia Delgado Demera \\ Universidad Técnica de Manabí UTM, Manabí, Ecuador \\ http://orcid.org/0000-0002-5815-8981 \\ Silvia Marieta Aldaz Hernández \\ Universidad Nacional de Chimborazo UNACH, Riobamba, Ecuador \\ http:/ / orcid.org/0000-0003-0089-297X
}

\begin{abstract}
The aim of the research was to determine the virtual competences of Ecuadorian tourism teachers during the A-2021 cycle. A mixed research approach was used. A quantitative analysis was applied first, followed by a qualitative analysis. The sample selection was participatory and non-probabilistic. The sample consisted of 1003 active university teachers in Ecuador. A questionnaire comprising 106 questions divided into four variables was designed. A multivariate analysis of variance (MANOVA) and the Kruskal-Wallis test were carried out. The findings indicate the applicability of virtual competences by university teachers. These competences are of a medium level and do not comply with the comprehensive competences of student care. The technological training level of university teaching staff is low. Regarding the use and knowledge of technology, respondents indicated a high level of understanding. Attitudes towards and methodology use in information and communication technologies showed weaknesses in usage and accessibility. In conclusion, a matrix of virtual competences for university tourism teachers is presented. The application of this methodology
\end{abstract}


considers the competences in a comprehensive and problem-oriented manner.

Keywords: university education; teaching staff; competences; virtual education; technology

\section{Introduction}

Since 2020, educational status worldwide has undergone a radical change. On 19 March 2020, as in other countries, a health alert was issued in the Republic of Ecuador. A state of quarantine was declared due to the SARS-CoV-2 pandemic (Covid-19). We live in a globalized world in which knowledge is constantly generated. By virtue of the vertiginous scientific and technological progress, and organizational changes, students emerge with different training needs, challenged by time constraints, greater responsibilities, and difficulties in processing the almost infinite amount of information (Cuesta, 2018).

In response to this reality, virtual education is emerging as an alternative solution bringing education to the most remote places, anytime, anywhere. Virtual education enables educators to take advantage of the benefits of technology and thereby offer better options to students who require professional training (Hurtado, 2018). Educators thus are fulfilling multiple responsibilities, while at the same time updating their knowledge and skills and undergoing continuous professional training (Gispert, 2003). These new ways of educating bring with them new demands on universities. In a context that intensively incorporates technologies, such as the virtual modality, the responsibility for training does not fall on a single person. Responsibility lies with the whole university. The educational organization is responsible for the curricular design (objectives, contents, methodology, assessment and evaluation), and the production of materials and resources. To this end, a multidisciplinary team is required to coordinate the content creation process (Standish, 2016), as well as the teaching activities which are developed by the same team or by a group of external professionals. This multidisciplinary team should comprise:

- Programme coordinator.

- Content author.

- Didactic designer.

- Technical designer.

- Tutor (subject and research advisor).

- Teacher (tutor, facilitator of the subject).

The tourism teacher is seen as the professional who delivers the programme according to the materials previously compiled. The teacher interacts directly with the students or participants. He/she is the one who assumes the tasks of activity designer, responsible for tutoring and learning assessment (Biesta \& Säfström, 2018). In a training space supported by technologies, the action of the tourism teacher changes. Teachers must place themselves in this new context by knowing how to guide the teaching-learning process. Their role as the main source of information or knowledge provider ceases and gives way to the process of mediation. This process produces the construction of shared knowledge as the 
basis for learning. Students, materials and the university are sources of knowledge and skills required for learning.

The changes brought about in higher education by the Covid-19 pandemic require effective action. This reality requires tourism teachers (TTs) to assume roles and tasks for which they have not been prepared. They are required to recreate in the virtual environment situations that work very well in the face-to-face environment. However, they do not obtain the same results in this context. The TTs in the face-to-face setting feel at ease; they have mastered didactics, they know their resources, and they know how to reach their students. But in a virtual environment they become disoriented or assume that the students will do the work themselves. In the most innovative virtual environments, it is not a matter of students and teachers doing the same as in the face-to-face situation. In the new educational environments, responsibilities and tasks also change substantially. Commitments to ways of teaching and learning are different (Scull et al., 2020).

\section{Literature Review}

\subsection{Educational competences}

In higher education, learning is determined by competences. Competences are necessary qualities that a professional requires for optimal job performance (Van Griethuijsen et al., 2020). ICT (Information Communication Technology) enables the TTs to engage their students in new virtual learning environments (VLEs). Attitudes characterize cooperation in the knowledge society; learners need to develop skills at a personal level, and competences must be acquired to be able to cope in today's digital society. These aspects (attitudes, skills, competences) characterize the educational context of higher education. An example of attitudes can be altruism. Altruism is necessary to generate knowledge and to be able to share it with others without expecting anything in return. People create, share and elaborate on knowledge through continuous and rapid processes. This process is known as feedback. There is also respect for the work of others, not appropriating it, but building on it (Van Griethuijsen et al., 2020).

Long before the Covid-19 pandemic, Alonso and Blázquez (2012) established four integral digital competences, namely the "Knowing" competence (knowledge that a person possesses), the "Knowing how to do" competence (skills and abilities of the individual), the "Knowing how to be" competence (attitudes that guide their behaviour and decisions), and the "Knowing how to live together" competence (attitudes that the person assumes internally and/or in relation to the environment). Osbeck et al. (2018) maintain that for teachers to have these competences, they must receive conceptual training in ICT. Competences transform and support the learning and teaching environment. This can help to change beliefs about ICT. Competences help TTs to stay updated on and informed about their work. The competences strengthen their own educational content and resources. These competences render the TT competitive. They allow TTs to change the role of repeater of tourist experiences to a generator of knowledge.

\subsection{Virtual education in universities}

Virtual university education should focus on three dimensions: firstly, the means of communication; secondly, the teaching staff; and thirdly, the student body 
(Mendoza et al., 2021). The first dimension prioritizes technological tools and the approach to the teaching-learning process (Loeng \& Omwami, 2018). In the second dimension, and dominant at the higher level, is the teacher. The teacher is constructed as the only valid judge of knowledge. This knowledge is conceived as transmissible. In other words, this concept of learning is strongly linked to classical methodological models (Roessger et al., 2020). The third dimension constitutes the student body and self-training (Hirsch, 2016). Current day universities require an integrative model, articulating the three dimensions in search of an open and flexible methodology. This virtual model places the student as the protagonist of learning situations (Hooshyar et al., 2019). The characteristics acquired by this methodological adaptation, virtual education and TTs' competences are the focus of analysis of this study.

\subsection{Research problem}

Despite the great commitment to and demand in higher education, changes have not been an impediment for Ecuadorian universities. The implementation of strategic actions, such as training programmes, supervised accompaniment, mentoring, and collaborative expert support, are examples of what is required (Kümmel et al., 2020). In Ecuador, university academic programmes in tourism do not offer digital pedagogical training (Mendoza et al., 2019). To do this, it is necessary for the TTs to develop digital educational competences (Bilbao, 2008) competences that enable them to efficiently assume the responsibilities of the training process in a VLE. Likewise, these competences must be easily assessable to establish mechanisms for continuous supervision and guidance (Aguilar, 2015), and to be evaluated by university academic coordinators. In addition, the competences should enable the design of teacher training programmes to be promoted (Mendoza et al., 2019). In the Republic of Ecuador there are no official competence standards that serve as a reference for e-learning. Although there are guidelines issued by the Higher Education Council for distance education (CES, 2015), these guidelines do not specify the TTs' competences required for VLEs. Based on the problems raised, the following questions emerged:

- How should we assess the digital competences of Ecuadorian tourism teachers in virtual learning environments?

- What are the digital competences most applied by Ecuadorian university tourism teachers during the Covid-19 pandemic?

- What are the levels of technological literacy of Ecuadorian university tourism teachers?

- Which educational methodology is used by university tourism teachers in the educational sciences?

- What is the level of ICT training received by the TTs and how are their training needs detected?

- What are the attitudes of Ecuadorian university TTs towards ICT?

- What are the optimal competences of the TTs to strengthen e-learning environments? 


\subsection{Research objectives}

To answer the above questions, the following objectives were proposed:

To

- design and construct a reliable and valid questionnaire to analyse, describe and evaluate the application of digital competences in tourism education,

- establish and describe the use of technology and technological literacy of Ecuadorian university TTs,

- describe and analyse the methodological level of the Ecuadorian TTs in education,

- determine and analyse the level of ICT training received by TTs and detect their training needs,

- establish and describe the level of the attitude towards ICT of Ecuadorian TTs in Education, and

- identify and standardize university TTs' competences for a virtual learning environment - competences that may serve as a reference for subsequent training and evaluation actions.

\section{Methodology}

\subsection{Type of research}

Due to the nature of the study, the type of research was multi-method or mixed method. Mixed methods are based on the simultaneous use of qualitative and quantitative methods (Núñez, 2017). The mixed-method study encompasses descriptive and interpretive research. Descriptive research seeks to detail the most representative entities of the individuals, which were subjected to the researchers' analysis. Interpretative analysis is characteristic of social studies (UPEL, 2016). Interpretative studies make it possible to explain and understand more complex social facts or phenomena. These studies are based on a theoretical framework, manifestos or interviews. They are in-depth studies of social facts or cultural phenomena. In this study descriptive and interpretative research allowed the collection of information on relevant aspects, describing the current reality of the TTs' profile - realities perceived in the activities of the university platforms (Mendoza et al., 2019).

\subsection{Research design}

The research design was nested or a simultaneously integrated design of the dominant qualitative model (DIAC) (Hernández et al., 2014). The DIAC design collects quantitative data through surveys or questionnaires. Statistical studies (quantitative analyses) are then applied. The data are quantified according to the variables in the instruments. Data then are analysed interpretively by the authors (qualitative analysis). The researchers decided on this design, which allowed us to obtain the opinions of the Ecuadorian TTs. In this way, the optimal virtual competences required by the university TTs in Ecuador could be studied.

\subsection{Population and sample}

According to Arias (2012), the population is the total set of informants. The sample only determines a subset to which access is available. In the Republic of Ecuador 31 universities have Faculties of Tourism. The population consisted of 5109 tourism teachers (see Senescyt, 2021). For the selection of the sample, the non- 
probabilistic sampling technique was applied. This technique involved voluntary participation. The researchers established criteria that allowed the selection of participants (Hernández et al., 2014). This type of sampling also is known as selfselected. For reasons of health care and prevention (Covid-19 pandemic), agglomerations and face-to-face surveys could not be conducted. The researchers sent an e-mail invitation to participate to the active TTs. Those who accepted were considered the study sample. The criteria for participation were simple, for example: "I am willing to voluntarily participate in the study" (see Vega et al., 2019). The sample consisted of 1003 TTs participants. This sample represented $19.63 \%$ of the Ecuadorian university TTs in the A-2021 cycle.

\subsection{Hypotheses of the research}

The study of descriptive hypothetical character, raised the following hypotheses:

- $\mathrm{H}_{0}$ : null hypothesis: Ecuadorian university TTs during the A-2021 cycle do not use digital competences in virtual learning environments.

- $\mathrm{H}_{1}$ : alternative hypothesis: Ecuadorian university TTs during the cycle A2021 use digital competences in e-learning environments.

\subsection{Data collection techniques and instruments}

Data collection techniques are defined as the means of interacting with participants (Hurtado 2018). For data collection, digital questionnaires were applied. This instrument is the most widely used in quantitative research in times of a pandemic (Arshad et al., 2021). The choice of this instrument allowed for an overview of the digital competence of the TTs (Mendoza et al., 2019), as well as a deeper insight into the reality of ICT in Ecuadorian TTs during the A-2021 cycle. To respond to the first objective, a digital questionnaire was designed, divided into four variables recommended by Agreda et al. (2016): (i) Use and literacy of technology (variable 1, see Appendix 1); (ii) Educational methodology through ICT (variable 2, see Appendix 2); (iii) University TTs training in ICT (variable 3, see Appendix 3); (iv) Attitude towards ICT in higher education (variable 4, see Appendix 4). The questionnaire contained a selection of items, and a scale of quantitative values to measure the degree of acceptance or rejection of each item (Cecchini et al., 2018). The questionnaire had five response items (option 1=nil, option $2=$ low, option $3=$ medium, option $4=$ high, option $5=$ very high). The written record quantified attitudes, ranking and recording degrees of approval and impact (Matas, 2018). The questionnaire was structured in 106 items, divided into four variables.

\subsection{Reliability}

The level of reliability of a measurement instrument refers to the accuracy (Barraza \& Barraza, 2018). To determine reliability, Cronbach's alpha coefficient was calculated. A pilot test was applied with ten tourism teachers. Table 1 shows the results obtained through the Statistical Package for Social Sciences (SPSS), version 25 software. The statistical coefficient was on average .901. Results within the range of 0.7 to 0.9 indicate a good internal consistency for this scale (González \& Pazmiño, 2015; Mendoza et al., 2021). 
Table 1: Values obtained for Cronbach's alpha reliability coefficient

\begin{tabular}{|c|c|c|c|c|}
\hline \multicolumn{5}{|c|}{ Cronbach Alfa } \\
\hline Questionnaires & Variation of the elements & SD & $\mathbf{N}$ & a \\
\hline Variable 1 & .890 & .590 & 36 & .901 \\
\hline Variable 2 & .892 & .359 & 32 & .906 \\
\hline Variable 3 & .901 & .427 & 22 & .874 \\
\hline Variable 4 & .913 & .586 & 16 & .926 \\
\hline \multicolumn{3}{|c|}{ Total } & 106 & .901 \\
\hline
\end{tabular}

\subsection{Statistical analysis of the data}

In the quantitative phase of the research, the Kruskal-Wallis test and the multivariate analysis of variance (MANOVA) were applied. With MANOVA, differences between groups are analysed based on multiple dependent variables (Holmes, 2020). This technique is an extension of ANOVA; it considers two or more dependent variables simultaneously. The MANOVA is a dependence technique that allows estimating significant differences between the means of several variables by comparing them jointly. This means that $\mathrm{N}$ subjects are assessed or measured on $\mathrm{M}$ variables. Multivariate analysis attempts to explain the behaviour of such subjects by means of a set of common factors. Other specific factors are also added. These factors include the characteristics of each variable plus chance or error. The aim is to find the group of variables with a common meaning. The MANOVA allows for reducing or unifying the number of variables that are necessary for the explanation of the major information that is contained in the data.

\subsection{Qualitative analysis of the results}

After establishing the data analyses, the final qualitative analysis was carried out. The results were interpreted through data triangulation. Triangulation made it possible to combine theoretical contributions, texts, previous studies, questionnaires, external opinions, and interpretation of authors, among others (Aguilar \& Barroso, 2015). In this way, the university TTs' optimal competences were formulated for the EVL during the A-2021 cycle.

\section{Findings}

\subsection{Data analysis}

Once the participating teachers had completed the survey, the researchers tabulated the non-parametric data as recommended by Holmes (2020). Statistical data were analysed, and the sum of frequencies, variances, deviations and means were obtained. The four study variables were independent. To check whether the variables were directly related to digital competences, the Kruskal-Wallis test was applied (see Table 2). 
Table 2: Kruskal-Wallis test

\begin{tabular}{|c|c|c|c|}
\hline & Group & N & $\begin{array}{c}\text { Mean } \\
\text { Rank }\end{array}$ \\
\hline \multirow{3}{*}{$\begin{array}{c}\text { Digital competences of university } \\
\text { teaching staff }\end{array}$} & Variable 1 & 36 & 45.98 \\
\cline { 2 - 4 } & Variable 2 & 32 & 38.12 \\
\cline { 2 - 4 } & Variable 3 & 22 & 23.89 \\
\cline { 2 - 4 } & Variable 4 & 16 & 18.56 \\
\hline & Total & 106 & \\
\hline
\end{tabular}

This test agrees to accept or reject the hypotheses. It also allows to check whether the samples come from the same population (Ostertagová et al., 2014). Then, in the statistical test, Chi-square and asymptotic significance can be distinguished (see Table 3).

Table 3: Results test statistic

\begin{tabular}{|l|c|}
\hline & Digital competences of university teaching staff \\
\hline Chi-Square & 3.568 \\
\hline df & 4 \\
\hline Asymp. Sig. & .038 \\
\hline
\end{tabular}

The results show that the significance asymptote p .038<.05. With a $95 \%$ confidence interval, the null hypothesis is rejected and the alternative hypothesis is accepted. The variables tested are associated with the population from which the sample was drawn. The results showed that there were significant statistical differences. The multivariate test was then applied to find out if there were significant differences between the group means (Özlem et al., 2019) (See Table 4).

Table 4: Multivariate test of the research variables

\begin{tabular}{|c|c|c|c|c|c|c|}
\hline \multicolumn{7}{|c|}{ Multivariate Tests } \\
\hline & Effect & Value & $\mathrm{F}$ & Hypothesis df & Error df & Sig. \\
\hline \multirow{4}{*}{ Group } & Pillai's Trace & .447 & 43.680 & 3.000 & 2994.000 & .048 \\
\hline & Wilks' Lambda & .605 & 45.898 & 3.000 & 2635.460 & .047 \\
\hline & Hotelling's Trace & .569 & 47.131 & 4.000 & 2984.000 & .039 \\
\hline & Roy's Largest Root & .368 & 91.825 & 5.000 & 998.000 & .042 \\
\hline
\end{tabular}

The data showed that there were significant differences among the variables; in the case of homogeneous variance for four variables. The multivariate test rendered the following data: with the Pillai's trace statistic the samples are balanced by having a coefficient of $0.048<0.050$; the Wilk's Lambda coefficient with a value of $.047<0.050$; the Hotelling's Trace with a value of $.039<0.050$; and Roy's Largest Root with a value of $.042<0.050$. Discriminant analysis was then applied (see Table 5). This analysis provided insight into the nature of the differences that existed among the variables (Lateef et al., 2015). 
Table 5: Presentation of the structure matrix

\begin{tabular}{|c|c|c|c|c|c|c|c|c|c|c|}
\hline \multicolumn{11}{|c|}{ Structure Matrix } \\
\hline & \multicolumn{5}{|c|}{ Options } & \multirow{2}{*}{ Mean } & \multirow{2}{*}{$S D$} & \multirow{2}{*}{ Min } & \multirow{2}{*}{ Max } & \multirow{2}{*}{$\mathrm{N}$} \\
\hline & 1 & 2 & 3 & 4 & 5 & & & & & \\
\hline $\begin{array}{l}\text { Variable } 1 \text { (Use and ICT literacy in higher } \\
\text { education) }\end{array}$ & .328 & 3.489 & .523 & .620 & .578 & 4.02 & .529 & 1.98 & 5.08 & 36 \\
\hline $\begin{array}{l}\text { Variable } 2 \text { (Educational methodology through } \\
\text { ICT) }\end{array}$ & .598 & 3.682 & .862 & .702 & .697 & 3.15 & .714 & 1.18 & 4.21 & 32 \\
\hline $\begin{array}{l}\text { Variable } 3 \text { (Training of university faculty in } \\
\text { ICT) }\end{array}$ & .082 & 2.609 & .576 & 401 & .098 & 2.89 & 428 & 1.94 & 5.01 & 22 \\
\hline $\begin{array}{l}\text { Variable } 4 \text { (Attitude to ICT in higher } \\
\text { education) }\end{array}$ & .499 & .659 & .702 & 690 & .611 & 3.27 & .586 & 1.92 & 5.09 & 16 \\
\hline Total & & & & & & 3.33 & .564 & 1.75 & 4.84 & 106 \\
\hline
\end{tabular}

To answer the second objective, variable 1, with a coefficient of 0.620 (option 4), demonstrates the level of importance of each of the response options. It shows that Ecuadorian university TTs regard a high level of technology use and literacy as very important.

In response to the third objective, variable 2 rendered a coefficient of 0.862 (option 3). It indicates a medium level of importance of educational methodology making use of ICTs.

In answer to objective four, variable 3 presented a coefficient of .609 (option 2). This shows that university TTs' level in technological educational training was low.

Finally, to answer objective five, variable 4 had a coefficient of .702 (option 3). This shows that TTs' attitudes towards ICT reflected a medium level. The mean of the digital competences possessed by the TTs is 3.33, demonstrating a statistical mean of 3.33 (medium level).

\subsection{Qualitative analysis and discussion of the results}

The study of the digital competence of university TTs is indispensable, especially for those researchers dedicated to the study of tourism training with technology. It is important to be aware of the evolution that has occurred in education and training over the past two decades to describe the current situation. The statistical results with an SD of .428 show that variable 3 is the most important variable. Variable 3 represents the Integral Competence of "Knowing how to be" (Alonso \& Blázquez, 2012). It is related to the training of university faculty in ICT. To "know how to be", the TTs must assess the strengths and weaknesses of technological means. This integral competence is assessed through training. Through training, the ethical principles of the use of technologies are respected (Kümmel et al., 2020). Curiosity about and motivation for continuous learning must also be present. Improving the use of technologies, the competence of lifelong learning offers a gradual development scheme. Competences go beyond the basic technological training. They comprise initial and continuing training (Azmi \& 
Noer, 2020). Initial training familiarizes teachers with basic ICT recognition and handling (Loeng \& Omwami, 2018).

The results showed that Ecuadorian university TTs have a low level of technological training, ensuing in problems such as the need for continuing education. The need is not so much at the instrumental level, but in seeing and using technologies as a pedagogical and didactic resource. Therefore, the TTs require technological updating, to receive training and to gain knowledge of new technological-educational trends, as well as ongoing training in the integration of ICT, and the identification of digital educational materials. Second, variable 1, with an SD of .529, is categorized as the integral competence of "Knowing". Knowing is considered the cognitive-reflective level of the teacher (Adam, 1990). This competence is related to epistemological knowledge, required for the development of theoretical teaching actions as recommended by Roessger et al. (2020). The main qualities that this competence provides are:

- High-level mastery of the subject.

- Up-to-date knowledge.

- Mastery of research methodology.

- Mastery of university education.

Statistical values demonstrated a high level of knowledge. Knowledge competence allows creating and editing new digital content, and integrating and reviewing previously obtained knowledge (Grünwald et al., 2016). Knowledge competence facilitates artistic productions, creating multimedia content and computer programming. This competence favours the development of digital content. Thirdly, we have variable 4 with an SD of .586. This variable is related to the integral competence of "Knowing how to live together". It is known that attitude is immersed in communication (Alcalá, 1999). Digital environments share resources through online tools. The TTs must know how to use and coexist with these means of connection (Snyman \& Van den Berg, 2018). Communicative connection and collaboration with faculty are important (Snyman \& Van den Berg, 2018). Digital tools help to interact and participate in communities and networks. In this way, intercultural digital awareness is generated (García, 2014).

Attitude towards ICT is understood as the affective and communicative dimension (Espinoza et al., 2020). These competences are qualities related to social and communicative skills (INSTIA, 1986). Personal attitudes can establish affective and communicative links. According to Cela et al. (2017), the most common social skills competences are:

- Facility for interpersonal relationships.

- Affective personality traits.

- Specific organizational teaching skills.

- Long-term and short-term planning of learning activities.

- Selection of teaching methods.

The results show that the attitudes of university TTs towards ICT are at a medium level. If this competence is merely at a medium level, there is no effective teacherstudent relationship. This influences the learning of university tourism students 
(García et al., 2014), because personal relationships between teachers and students always impact teaching and learning. A lack of competence does not facilitate the $\mathrm{TT}^{\prime}$ 's role as a trainer. First establish communication, then trust will follow, and mutual respect is formalized (Roessger et al., 2020). Thus, communication is an essential digital competence in VLEs (Samuel et al., 2019).

Variable 2, methodology, with an SD of .714 is related to the integral competence "Know-how". This competence comprises the active-creative dimensions of the teacher (Arocena, 2014), and is of an applicative nature in education, meaning that knowledge and skills are worth nothing if they cannot be applied. This competence to 'know how', or apply enables all TTs to design, develop, implement, and evaluate effective and efficient activities. . The results showed that the methodological level of the TTs was rated at medium level, implying that teachers needed to improve their problem-solving skills (Pérez, 2009). The TTs must know how to choose the most appropriate digital tool for a specific task. They must also be able to solve conceptual problems through digital media, and must know how to apply technologies creatively and solve technical problems. If teachers cannot identify technological needs, they cannot establish innovation creatively (Azmi \& Noer, 2020).

Teachers with a low or medium level of competence in methodology do not perform efficient digital assessment (Pellón, 2013). Thus, Ecuadorian TTs should opt for a flexible academic model to avoid excessive homework and the overload of online activities. Krichesky and Murillo (2018) advise that teachers update their skills and knowledge to promote innovation. Innovative teaching means leaving behind the old to look for what will work in the future (Díaz, 2006). Being informed about technological innovation strengthens solutions in the educational context. López and Pérez (2017) emphasises the importance of implementing the epistemological basis of university digital didactics. Digital didactics is innovative and facilitates teaching in higher education (CERPE, 2010). To solve problems, teachers must be open to reflective criticism (Rodríguez, 2016), as. critical, inquisitive attitudes serve well in being constructive for the teacher (Roessger et al., 2020). Finally, digital competence learning is the application of skills in VLEs, but these skills, abilities, attitudes and values need to be developed by the TTs. The role of the university TTs is to leave behind traditional learning models. In virtual education, accompaniment and knowledge construction go hand in hand. The mastering of competences requires constant skills development. The findings of this study indicate that digital competences are important in Ecuadorian higher education. Among the results of the research, four integral competences have been ranked ordinally, establishing the order in which they should be developed.

\section{Conclusions}

Based on the results obtained, and according to Espín (2019), the university technological professional environment must prioritise "learning to learn". University TTs have not learned digital teaching strategies. Most of them have not been trained in digital education, nor in virtual platforms. Due to the COVID-19 pandemic TTs are faced with a new task, namely on-line teaching, but few are fully informed on how to deal with today's digital challenges. TTs believe that 
students already know everything they need to do. The Ecuadorian university works in a forced digital information society (Mendoza et al., 2021). The emergence of the COVID-19 pandemic caused traditional face-to-face education to make changes for which it was not prepared. To apply ICT in education, TTs need to know how to organise data and information, to select what is most important and relevant, and how to convert these into digital knowledge to be used efficiently and effectively through university on-line platforms. TTs thus must assimilate, master and implement strategies that enable them to plan and organise. However, today's university education in Latin American society is the product of profound changes In the cultural, social, political and economic spheres. These changes drive the reality of each social context, striving for progress. Tourism training plays a fundamental role in the development of countries. Universities are to promote the development of human talent, creating economic income for the country, and the production and updating of knowledge, science, technology, and research. These advances allow each nation to benefit from the human resources trained. However, if professional competences remain stagnant in a traditional system, there will be no significant progress. Therefore, to respond to objective 6 , the optimal competences of university TTs are presented in Table 6.

Table 6: Optimal competences of university tourism teachers for a virtual learning environment.

\begin{tabular}{|c|c|}
\hline $\begin{array}{l}\text { ICT training for } \\
\text { university tourism } \\
\text { teaching staff }\end{array}$ & $\begin{array}{l}\text { - Apply self-assessment of personal skills and abilities. } \\
\text { - Know the platform and its working tools. } \\
\text { - Value the means through which communication is } \\
\text { established to facilitate learning. } \\
\text { - Be a professional in tourism and virtual platforms. } \\
\text { - Learn and implement models of didactic training and critical- } \\
\text { constructive development. } \\
\text { - Understand that research and digital innovation should be } \\
\text { parallel components of university education. } \\
\text { - Be a lifelong learner in virtual tourism education. } \\
\text { motivated and willing to apply self-improvement. }\end{array}$ \\
\hline $\begin{array}{c}\text { Technology use } \\
\text { and literacy }\end{array}$ & $\begin{array}{l}\text { - Use digital feedback systems to serve a larger number of } \\
\text { students and assertively inform them of their training in } \\
\text { tourism. } \\
\text { - Demand the generation of new contributions to tourism } \\
\text { education (research). } \\
\text { - Create change, recognizing that there is no single truth. } \\
\text { - Value the students' tourism experiences. } \\
\text { - Generate a process of virtual experimentation-action. } \\
\text { - Give assurance of availability of tourism information at any } \\
\text { time and from anywhere. } \\
\text { - Ensure that tourism students are comfortable with the system } \\
\text { and the software. } \\
\text { - Keep in contact with the university platform administrator. } \\
\text { - Monitor student progress and review virtual tourism } \\
\text { activities. }\end{array}$ \\
\hline
\end{tabular}




\begin{tabular}{|c|c|}
\hline & $\begin{array}{l}\text { - Establish the overall course schedule by modules, } \\
\text { assignment submission, and follow-up of the different } \\
\text { communication activities. } \\
\text { - Establish dates and times for chats and forums. } \\
\text { - Use web-based recording media. }\end{array}$ \\
\hline $\begin{array}{l}\text { Attitude towards } \\
\text { ICT in higher } \\
\text { education }\end{array}$ & $\begin{array}{l}\text { - Ability to offer knowledge content to many students at } \\
\text { different times. } \\
\text { - Treat the students with elements of digital tourism education. } \\
\text { - Hold reflective dialogues. } \\
\text { - Foster effective communicative relationships with students to } \\
\text { create empathy. } \\
\text { - Be supportive and participative in the tourism knowledge } \\
\text { society. } \\
\text { - Encourage reflection and act with maturity. } \\
\text { - Understand that knowledge must be put into practice } \\
\text { through virtuality. } \\
\text { - Encourage collaborative rural tourism. Manage learning } \\
\text { groups for networking. }\end{array}$ \\
\hline $\begin{array}{c}\text { Educational } \\
\text { methodology } \\
\text { through ICT }\end{array}$ & $\begin{array}{l}\text { - Develop classes based on tourism competences. } \\
\text { - Use evaluation software to measure competences. } \\
\text { - Master independence and time management skills for better } \\
\text { tourism planning. } \\
\text { - Establish innovative changes in digital teaching and learning } \\
\text { processes. } \\
\text { - Develop theoretical-conceptual contents. Favour the } \\
\text { comparison of epistemic training in tourism environments. } \\
\text { - Maintain a corrective and motivating digital evaluation } \\
\text { process. } \\
\text { - Generate processes of self-evaluation, evaluation and co- } \\
\text { evaluation. } \\
\text { - Be flexible and not rigid in setting deadlines for the delivery } \\
\text { of virtual activities and evaluations. Understand that internet } \\
\text { or hardware failures may occur. } \\
\text { - Offer guidance tutorials for activities, assessments and } \\
\text { tourism research. } \\
\text { - Ensure that tourism students are reaching the appropriate } \\
\text { level of competence. } \\
\text { - Introduce the discussion topic and relate it to the previous } \\
\text { learning. } \\
\text { - Resolve possible doubts arising from the reading of the } \\
\text { teaching materials. Explain how to carry out the virtual } \\
\text { tourism activities. } \\
\text { - Make overall and individual evaluations of the virtual } \\
\text { tourism activities. }\end{array}$ \\
\hline
\end{tabular}

\section{Recommendations}

Digital competences in tourism are of utmost importance for university teachers. Competences are qualities that imply the creative, critical and safe use of ICT to achieve the established objectives. Therefore, the following recommendations are made: 
- Provide emotional support to tourism faculty, especially those who experience greater difficulties in the adaptation of digital competencies.

- Generate spaces to share experiences of distance learning among tourism teachers.

- Establish support networks with ICT and tourism teachers to increase tourism knowledge. Increase tourism knowledge.

- Train tourism teachers in digital tools and methodologies for remote work, among others.

- Apply the digital competencies developed in this study.

\section{Limitations}

The research was carried out considering only university teachers of tourism. The study depended on the reliability and authenticity of the data. Another limitation is the sample size. Samples of more than 50 informants are required to generalise results. Data collection instruments preferably should be parametric, while variables must be ordinal. Preferably only three or five response options should be provided; not even response options.

The methodological design was multi-method, which is an advantage as data could be triangulated.

\section{References}

Adam, F. (1990). Andragogy and University Education. Fondo Editorial Andragógico de FIDEA.

Agreda, M., Hinojo, M. \& Sola, M. (2016). Design and validation of an instrument for assessing digital skills of teachers in Spanish higher education. Revista de Medios y Educación, 49, 39-56. https://www.redalyc.org/pdf/368/36846509004.pdf

Aguilar, J. (2015). Research challenges in teacher training at the upper secondary level in Mexico. Perfiles Educativos, 37, 89-107. http://www.scielo.org.mx/pdf/peredu/v37nspe/v37nspea7.pdf

Aguilar, S. \& Barroso, J. (2015). Data triangulation as an educational research strategy. Revista de Medios y Educación, 47, 73-88. http://dx.doi.org/10.12795/pixelbit.2015.i47.05

Alcalá, A. (1999). Andragogy: Study Guidebook. Universidad Nacional Abierta UNA.

Alonso, B. \& Blázquez, E. (2012). The virtual education teacher. Narcea Ediciones.

Arshad, M., Vivek, M., Kamalun, M., Khojah, M. \& Tahir, M. (2021). Students' Perception towards E-Learning during COVID-19 Pandemic in India: An Empirical Study. Sostenibilidad, 13, 57. https://dx.doi.org/10.3390/su13010057

Arias, F. (2012). The Research Project. Episteme Editorial.

Arocena, R. (2014). University research on the democratization of knowledge. Revista Iberoamericana de Ciencia, Tecnología y Sociedad, 9(27), 85-102. https://www.redalyc.org/pdf/924/92431880005.pdf

Azmi, M. \& Noer, F. (2020). The andragogical approach for teaching english speaking skill for college students. Journal of Applied Science, Engineering, Technology, and Education, 2(2), 136-140. https://doi.org/10.35877/454RI.asci2264

Barraza, A. \& Barraza, S. (2018). Evidence of validity and reliability of the scale of academic expansion in a Mexican student population. Revista de Psicología y Ciencias del Algote, 9 (1), 75-99. http://www.scielo.org.mx/pdf/rpcc/v9n1/20071833-rpcc-9-01-75.pdf 
Biesta, G. \& Säfström, C. (2018). A Manifesto for Education. Praxis educativa, 22(2), 20-36. http://dx.doi.org/10.19137/praxiseducativa-2018-220203

Bilbao, C. (2008). Perfil profesional del profesor universitario. Dólmenes.

Cecchini, J., Méndez, A. \& García, C. (2018). Validation of the emotional intelligence questionnaire in physical education. Revista de Psicología del Deporte, 27(1), 8796. https://archives.rpd-online.com/article/download/v27-n1-cecchini-estradamendez-etal/1966-11102-1-PB.pdf

Cela, J., Esteve. V., Esteve, F., González, J. \& Gisbert, M. (2017). The professor of digital society: A proposal based on transformative pedagogy and advanced technology. Revista de Currículum y Formación de Profesorado, 21(1), 403-422. https://www.redalyc.org/pdf/567/56750681020.pdf

Centre for Educational Planning and Reflection, CERPE. (2010). Formación del profesorado. Serie de educación básica el perfil del profesor y su formación [Teacher training. Basic education series the teacher's profile and training]. Venezuela: Editorial CERPE.

CES (Consejo de educación Superior). (2015). Reglamento para carreras y programas académicos en modalidades en línea, a distancia y semipresencial o de convergencia de medios. Consejo de Educación Superior resolución RPC-SE-14No.043-2015. content/uploads/pdf/distancia/reglamento_para_carreras.pdf

Cuesta, O. (2018). Reconocimiento social del docente universitario: Subjetividad agobiada, puja por el prestigio académico y reivindicación del acto educativo [Social recognition of the university instructor: Oppressed subjectivity, bid for academic prestige, and revindication of the educational act]. The USB Agora/El ágora USB, 18(1), 54-71. http://doi.org/10.21500/16578031.3292

Díaz, S. (2006). Adult methodological learning strategies. Fondo Editorial Andragógico.

Espín, A. (2019). Aprendiendo a aprender - técnicas de estudio. Editorial UTA.

Espinoza, E., Villacres, G. \& Granda, D. (2020). Influence of technological didactics on

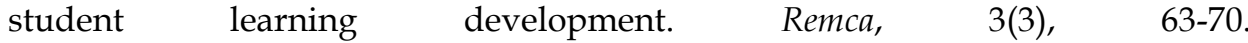
https://remca.umet.edu.ec/index.php/REMCA/article/download/311/335

García, E., García, A. \& Reyes, J. (2014). Master's students and their implications in the $\begin{array}{llll}\text { learning } \quad R a \text { Ximhai, } & \text { 10(5), 279-290. }\end{array}$ http:/ / www.redalyc.org/articulo.oa?id=46132134019

García, M. (2014). Assessing competencies in higher education by rubrics: a case study. Revista Electrónica Interuniversitaria de Formación del Profesorado, 17(1), 87-106. http://dx.doi.org/10.6018/reifop.17.1.198861

Gispert, C. (2003). Education Handbook. Editorial Océano.

González, J. \& Pazmiño, M. (2015). Calculation and interpretation of Cronbach Alpha for validation of the internal consistency of a questionnaire, with two possible Likert $\begin{array}{llll}\text { scales. Revista 2(1), } & \text { 2ública, }\end{array}$ https://revistapublicando.org/revista/index.php/crv/article/view/22/pdf_11

Grünwald, N., Pfaffenberger, K., Melnikova, J., Zaščerinska, J. \& Ahrens, A. (2016). A study on digital teaching competence of university teachers from Lithuania and Latvia within the Peesa Project. Andragogika, 1(7), 109-123. https:// core.ac.uk/download/pdf/233175481.pdf

Hernández, R., Fernández, C. \& Baptista, P. (2014). Research Methodology. Editorial: McGraw-Hill.

Hirsch, A. (2016). Responsible behaviour in unethical research and conduct at Mexican and Spanish universities. Revista de la Educación Superior, 45(179), 7993. http://publicaciones.anuies.mx/pdfs/revista/Revista179_S2A5ES.pdf 
Holmes, W. (2020). Multivariate analysis of variance for multilevel data: A simulation study comparing methods. The Journal of Experimental Education, 88, 1-16. https://doi.org/10.1080/00220973.2020.1718058

Hooshyar, D., Kori, K., Pedaste, M. \& Bardone, E. (2019). The potential of open learning models to promote active thinking by enhancing self-regulated learning in online higher education learning environments. Asociación Británica de Investigación Educativa, 50(5), 2365-2386. https://doi.org/10.1111/bjet.12826

Hurtado, A. (2018). University management: an educational praxis: Consubstantial with national development plans. Revista arbitrada del centro de investigación y estudios gerenciales, 28, 33-51. http:/ / www.grupocieg.org/archivos_revista/Ed.\%2028(3351)-Hurtado\%20Arturo\%20Jose_articulo_id300.pdf

Instituto Internacional de Andragogía, INSTIA. (1986). Theoretical Bases of Andragogy. Revista de Andragogía, 3(7), 45-68.

Krichesky, G. \& Murillo, F. (2018). Teach collaboration as a factor for learning and improving school: A case study. Educación XX1, 21(1), 135-156. https://www.redalyc.org/pdf/706/70653466007.pdf

Kümmel, E., Moskaliuk, J., Cress, U. \& Kimmerle, J. (2020). Digital Learning Environments in Higher Education: A Literature Review of the Role of Individual vs. Social Settings for Measuring Learning Outcomes. Educ. Sci, 10(78), 1-19. http:/ / dx.doi.org/10.3390/educsci10030078

Lateef, B., Waheed, B. \& Abubakar, U. (2015). A comparison of some test statistics for multivariate analysis of variance model with non-normal responses. Journal of Natural Sciences Research, 1-10. https://core.ac.uk/download/pdf/234656039.pdf

Loeng, S., \& Omwami, E. (2018). Various ways of understanding the concept of $\begin{array}{llll}\text { andragogy. } \quad \text { Cogent } \quad \text { Educación, } & \text { 1-15. }\end{array}$ http:/ / doi.org/10.1080/2331186X.2018.1496643

López, J. \& Pérez, I. (2017). Why are specific teachings needed for higher education? Revista Científica ECOCIENCIA, 5(1), 1-17. http:/ / revistas.ecotec.edu.ec/index.php/ecociencia/article/view/13

Matas, A. (2018). Likert-Type Scale Format Design: State of Art. Electrónica de Investigación Educativa, 20(1), 38-47. https://doi.org/10.24320/redie.2018.20.1.1347

Mendoza, D., Cejas, M., Rivas, G. \& Varguillas, C. (2021). Anxiety as a prevailing factor of performance of university mathematics students during the COVID-19 pandemic. The Education and Science Journal, 23(2), 94-113. https://doi.org/10.17853/19945639-2021-2-94-113

Mendoza, D., Abrigo, I., Romero, J., Cueva, F. \& Cejas, M. (2019). The formative research of Ecuadorian university teaching staff. Problems of education in the $21^{\text {st }}$ century, 77(3), 364-378. http://www.scientiasocialis.lt/pec/node/files/pdf/vol77/364378.Mendoza\%20Velazco_Vol.77-3_PEC.pdf

Núñez, J. (2017). Mixed methods in education research: Towards a reflexive use. Cadernos de Pesquisa, 47(164), 632-649. http:/ /dx.doi.org/10.1590/198053143763

Osbeck, C., Olof, F., Lilja, A. \& Sporre, K. (2018). Possible competences to be aimed at in ethics education: Ethical competences highlighted in educational research journals. Journal of Beliefs $\mathcal{E}$ Values, 39(2), 195-208. https://doi.org/10.1080/13617672.2018.1450807

Ostertagová, E., Ostertag, O. \& Kováč, J. (2014). Methodology and Application of the Kruskal-Wallis Test. Applied Mechanics and Materials, 611, 115-120. https://doi.org/10.4028/www.scientific.net/amm.611.115

Özlem, K., Emre, K. \& Mustafa, A. (2019). Comparison of test statistics of non-normal and unbalanced samples for multivariate analysis of variance in terms of type-I error 
rates. Computational and Mathematical Methods in Medicine, Article ID 2173638, 8. https://doi.org/10.1155/2019/2173638

Pellón, R. (2013). Watson, Skinner y ciertas disputas conductuales [Watson, Skinner, and certain disputes among behaviorists]. Revista Colombiana de Psicología, 22(2), 389399. https://dialnet.unirioja.es/descarga/articulo/4703413.pdf

Pérez, S. (2009). Modelos básicos de andragogía [Andragic model, basics]. Argentina: Campos Eliseos.

Roessger, K., Roumell, E. \& Weese, J. (2020). Rethinking andragogical assumptions in the global age: How preferences for andragogical learning vary across people and cultures. Estudios de Educación Continua, 42. http://dx.doi.org/10.1080/0158037X.2020.1732335

Rodríguez, A. (2016). Critique of constructive critique. Teoría y Crítica de la Psicología, 8, 212-221. https:/ / dialnet.unirioja.es/descarga/articulo/5895480.pdf

Samuel, Y., Mayra, M., Velazco, D., Santiago, L., Iván, S. \& Mauricio, B. (2019). Lonely and hate within social media. Revista Académica de Estudios Interdisciplinarios, 8(3), 7181.

http://www.richtmann.org/journal/index.php/ajis/article/view/10563/10188

Scull, J., Phillips, M., Sharma, U. \& Garnier, K. (2020). Innovations in teacher education at the time of COVID19: An Australian perspective. Journal of Education for Teaching, 46(4), 497-506. https://doi.org/10.1080/02607476.2020.1802701

SENESCYT (Secretaría de Educación, Superior Ciencia, Tecnología e Innovación). (2021). Sistema Integral de Información de Educación Superior (SIIES). https://siau.senescyt.gob.ec/imagenes/2020/10/Docentes_Universidades.xlsx

Snyman, Marici \& Van den Berg, Geesje. (2018). The Significance of the Learner Profile in Recognition of Prior Learning. Adult Education Quarterly: A Journal of Research and Theory, 68(1), 24-40.

Standish, P. (2016). Teaching Exposed: Education in Denial. Revista de Educación, 373, 109120. https:// doi.org/10.4438/1988-592X-RE-2016-373-323

UPEL (Universidad Pedagógica Experimental Libertador) (2016). Manual de Trabajos de Grado de Especialización y Maestría y Tesis Doctorales. FEDUPEL.

Van Griethuijsen, R., Kunst, E., Van Woerkom, M., Wesselink, R. \& Poell, R. (2020). Does implementation of competence-based education mediate the impact of team learning on student satisfaction? Journal of Vocational Education \& Training, 72(4), 516-535. https:// doi.org/10.1080/13636820.2019.1644364

Vega, V., Navarro, M., Cejas, M. \& Mendoza, D. (2019). Tourism planning and competitiveness in Ecuador. African Journal of Hospitality, Tourism and Leisure, 8(5), $1-10$.

https://www.ajhtl.com/uploads/7/1/6/3/7163688/article_16_vol_8_5_2019_ ecua dor.pdf 


\section{Appendix 1: Questionnaire for the variable, technology use and literacy}

\begin{tabular}{|c|c|c|c|c|c|c|}
\hline \multicolumn{2}{|r|}{$\begin{array}{l}\text { Digital competences of Ecuadorian tourism teaching staff during the } \\
\text { cycle A-2021 }\end{array}$} & \multicolumn{5}{|c|}{ Research } \\
\hline \multicolumn{7}{|c|}{$\begin{array}{l}\text { Instructions: Please respond to all items. Check with an X the box you consider best indicating } \\
\text { the degree to which you identify with each item. } \\
\text { Option } 1 \text { (null), option } 2 \text { (low), option 3(medium), option 4(high), option 5(very high). }\end{array}$} \\
\hline \multicolumn{7}{|c|}{ Date: $/ / /$} \\
\hline \multicolumn{2}{|c|}{ Gender: } & \multirow{2}{*}{\multicolumn{5}{|c|}{ Options }} \\
\hline $\mathrm{N}^{\circ}$ & Use and literacy of technology & & & & & \\
\hline \multirow[t]{4}{*}{1} & Knowledge and use of the basic components of ICTs & 1 & 2 & 3 & 4 & 5 \\
\hline & Peripherals & & & & & \\
\hline & External storage & & & & & \\
\hline & Digital whiteboard and projectors & & & & & \\
\hline \multirow[t]{3}{*}{2} & Knowledge and use of operating systems & 1 & 2 & 3 & 4 & 5 \\
\hline & Images and presentations & & & & & \\
\hline & Spreadsheet, database & & & & & \\
\hline \multirow[t]{4}{*}{3} & Use of the web and its basic tools & 1 & 2 & 3 & 4 & 5 \\
\hline & e-mail & & & & & \\
\hline & Browsers and search engines & & & & & \\
\hline & File-sharing tools & & & & & \\
\hline 4 & Knowledge and use of social networks & & & & & \\
\hline \multirow[t]{5}{*}{5} & $\begin{array}{l}\text { Management of resource distribution through web } 2.0 \\
\text { applications: }\end{array}$ & 1 & 2 & 3 & 4 & 5 \\
\hline & Blogs & & & & & \\
\hline & Wikis & & & & & \\
\hline & Video blog forums & & & & & \\
\hline & Online presentation & & & & & \\
\hline \multirow[t]{5}{*}{6} & $\begin{array}{l}\text { Management and use of tools and storage within cloud } \\
\text { environments }\end{array}$ & 1 & 2 & 3 & 4 & 5 \\
\hline & Google drive & & & & & \\
\hline & Dropbox & & & & & \\
\hline & I cloud & & & & & \\
\hline & Office 365 and SkyDrive & & & & & \\
\hline \multirow[t]{5}{*}{7} & Knowledge and use of manag & 1 & 2 & 3 & 4 & 5 \\
\hline & Moodle & & & & & \\
\hline & Blackboard & & & & & \\
\hline & Teams & & & & & \\
\hline & Other virtual platforms & & & & & \\
\hline 8 & $\begin{array}{l}\text { Handling of device protection software and care in Data } \\
\text { Protection }\end{array}$ & & & & & \\
\hline 9 & Knowledge and use of tools for creating QR codes & & & & & \\
\hline 10 & Knowledge of personal learning environments & & & & & \\
\hline 11 & Collaborative use of ICT collaboratively & & & & & \\
\hline 12 & $\begin{array}{l}\text { Development of materials using presentation, multimedia, } \\
\text { video and podcasts. }\end{array}$ & & & & & \\
\hline 13 & Knowledge of copyright and intellectual property & & & & & \\
\hline 14 & $\begin{array}{l}\text { Use of bibliographic managers (Zotero, Mendeley, Refwork, } \\
\text { Word Reference). }\end{array}$ & & & & & \\
\hline 15 & $\begin{array}{l}\text { Effective search and discrimination of relevant information on } \\
\text { the web. }\end{array}$ & & & & & \\
\hline
\end{tabular}




\begin{tabular}{|c|c|c|c|c|c|c|}
\hline 16 & Use of online publishing tools & 1 & 2 & 3 & 4 & 5 \\
\hline & Picassa & & & & & \\
\hline & Pinterest & & & & & \\
\hline & Instagram & & & & & \\
\hline & Slideshare & & & & & \\
\hline & Youtube & & & & & \\
\hline & TikTok & & & & & \\
\hline & Facebook & & & & & \\
\hline
\end{tabular}


Appendix 2: Questionnaire on the variable, educational methodology through ICTs

\begin{tabular}{|c|c|c|c|c|c|c|}
\hline \multicolumn{3}{|c|}{$\begin{array}{l}\text { Digital competences of Ecuadorian tourism teaching staff during the } \\
\text { cycle A-2021 }\end{array}$} & \multicolumn{4}{|c|}{ Research } \\
\hline \multicolumn{7}{|c|}{$\begin{array}{l}\text { Instructions: Please respond to all items. Check with an } X \text { the box you consider best indicating } \\
\text { the degree to which you identify with each item. } \\
\text { Option } 1 \text { (null), option } 2 \text { (low), option } 3 \text { (medium), option 4(high), option 5(very high). }\end{array}$} \\
\hline \multicolumn{7}{|c|}{ Date: } \\
\hline \multicolumn{2}{|c|}{ Gender: } & \multicolumn{5}{|c|}{ Options } \\
\hline $\mathrm{N}^{\circ}$ & Variable 2, Educational methodology using ICTs & 1 & 2 & 3 & 4 & 5 \\
\hline \multirow[t]{4}{*}{1} & $\begin{array}{l}\text { Implementation of experiences in and creation of learning } \\
\text { environments with ICT, and personalized educational } \\
\text { environments. }\end{array}$ & & & & & \\
\hline & Participation in research and teaching innovation projects & & & & & \\
\hline & Teaching experiences in the classroom through ICTs & & & & & \\
\hline & Participation in learning communities or learning networks & & & & & \\
\hline \multirow[t]{4}{*}{2} & Use of digital content as support & 1 & 2 & 3 & 4 & 5 \\
\hline & Online presentation & & & & & \\
\hline & Online video & & & & & \\
\hline & Self-made digital learning resources & & & & & \\
\hline 3 & Inclusion of virtual activities for learner acquisition & & & & & \\
\hline 4 & $\begin{array}{l}\text { Structuring subject activities using virtual university } \\
\text { campuses }\end{array}$ & & & & & \\
\hline 5 & Access to educational resources through different devices & & & & & \\
\hline 6 & $\begin{array}{l}\text { Use of web two zero tools such as blogs, wiki, podcasts, as } \\
\text { a subject activity }\end{array}$ & & & & & \\
\hline 7 & $\begin{array}{l}\text { Reproduce QR code to compile relevant information about } \\
\text { the syllabus such as bibliography of the subject and } \\
\text { complementary explanatory information on a topic }\end{array}$ & & & & & \\
\hline 8 & $\begin{array}{l}\text { Carrying out activities or tasks such as designs, project } \\
\text { outlines and explanations via QR codes }\end{array}$ & & & & & \\
\hline 9 & $\begin{array}{l}\text { Use of applications for the creation of augmented reality as } \\
\text { an educational resource }\end{array}$ & & & & & \\
\hline 10 & $\begin{array}{l}\text { Ability to create a virtual collaborative learning } \\
\text { environment }\end{array}$ & & & & & \\
\hline 11 & $\begin{array}{l}\text { Design of digital portfolios as a student self-development } \\
\text { activity }\end{array}$ & & & & & \\
\hline 12 & Use of video as digital learning material & & & & & \\
\hline 13 & $\begin{array}{l}\text { Use of virtual simulators and video games in the classroom } \\
\text { as a digital learning resource }\end{array}$ & & & & & \\
\hline 14 & $\begin{array}{l}\text { Providing students with ICT tools for planning and } \\
\text { organizing autonomous learning }\end{array}$ & & & & & \\
\hline 15 & $\begin{array}{l}\text { Use of cloud hosting tools to share educational material for } \\
\text { the subject and other relevant material for student training }\end{array}$ & & & & & \\
\hline 16 & $\begin{array}{l}\text { Assessment of the achievement of subject competences } \\
\text { using ICT }\end{array}$ & & & & & \\
\hline 17 & $\begin{array}{l}\text { Approach to and use of MOOCs as a complementary } \\
\text { learning resource }\end{array}$ & & & & & \\
\hline 18 & $\begin{array}{l}\text { Use of videoconferencing in class with experts in a field or } \\
\text { subject area of the course }\end{array}$ & & & & & \\
\hline
\end{tabular}




\begin{tabular}{|c|c|c|c|c|c|c|}
\hline 19 & $\begin{array}{l}\text { Effective development of digital tutoring for educational } \\
\text { enhancement }\end{array}$ & & & & & \\
\hline 20 & $\begin{array}{l}\text { Use of the digital whiteboard as a key element of ICT } \\
\text { training }\end{array}$ & & & & & \\
\hline 21 & $\begin{array}{l}\text { Use of social networking as a resource within the virtual } \\
\text { classroom }\end{array}$ & & & & & \\
\hline 22 & $\begin{array}{l}\text { Network-based subject learning, collaborative learning and } \\
\text { information sharing packages }\end{array}$ & & & & & \\
\hline 23 & $\begin{array}{l}\text { Evaluation of the methodology through online } \\
\text { questionnaires }\end{array}$ & & & & & \\
\hline 24 & $\begin{array}{l}\text { Management and knowledge of the functions of the virtual } \\
\text { classroom. }\end{array}$ & & & & & \\
\hline 25 & $\begin{array}{l}\text { Knowledge and use of tools for the creation of educational } \\
\text { activities through augmented reality }\end{array}$ & 1 & 2 & 3 & 4 & 5 \\
\hline & Applications: learnar, artookit, Aumentary & & & & & \\
\hline & Browsers: layar, junaio, wikitude world browser & & & & & \\
\hline & Knowledge about AR based projects: spira, Venturi & & & & & \\
\hline
\end{tabular}


Appendix 3: Questionnaire on the variable, university teacher training in ICT

\begin{tabular}{|c|c|c|c|c|c|c|}
\hline & $\begin{array}{l}\text { ital competences of Ecuadorian tourism teaching staff during } t \\
\text { cycle A-2021 }\end{array}$ & & & $\mathrm{arcl}$ & & \\
\hline $\begin{array}{l}\text { Inst } \\
\text { the } \\
\text { Opt }\end{array}$ & $\begin{array}{l}\text { uctions: Please respond to all items. Check with an X the box you cor } \\
\text { egree to which you identify with each item. } \\
\text { on } 1 \text { (null), option } 2 \text { (low), option 3(medium), option 4(high), option }\end{array}$ & & es & & & \\
\hline Date & $\therefore \quad / 1$ & & & & & \\
\hline Gen & der: & & & tio & & \\
\hline $\mathrm{N}^{\circ}$ & Variable 3, university teacher training in ICT & 1 & 2 & 3 & 4 & 5 \\
\hline 1 & Self-taught learning and experience of ICT & & & & & \\
\hline 2 & ICT problem-solving skills & & & & & \\
\hline 3 & ICT usage skills & & & & & \\
\hline 4 & Participation in ICT training courses & & & & & \\
\hline 5 & Received ICT training through e-learning & & & & & \\
\hline 6 & $\begin{array}{l}\text { Knowledge and integration of curriculum in e-learning } \\
\text { practice }\end{array}$ & & & & & \\
\hline 7 & $\begin{array}{l}\text { Lifelong learning of digital competence and educational } \\
\text { technology }\end{array}$ & & & & & \\
\hline 8 & $\begin{array}{l}\text { Training received in the use of mobile devices as a teaching } \\
\text { resource }\end{array}$ & & & & & \\
\hline 9 & $\begin{array}{l}\text { Training in software dedicated to research and data } \\
\text { collection processing }\end{array}$ & & & & & \\
\hline 10 & $\begin{array}{l}\text { Distinction between the different uses of ICT: educational } \\
\text { resource, leisure, communication, etc. }\end{array}$ & & & & & \\
\hline 11 & $\begin{array}{l}\text { Participation in innovation projects based on the use of } \\
\text { ICTs. }\end{array}$ & & & & & \\
\hline 12 & Dissemination of ICT experiences on the net & & & & & \\
\hline 13 & Creation and maintenance of a network of teacher contacts. & & & & & \\
\hline 14 & Evaluation of their teaching work with ICT & & & & & \\
\hline 15 & $\begin{array}{l}\text { Understanding and comprehension of national and } \\
\text { international indicators of digital competence }\end{array}$ & & & & & \\
\hline 16 & $\begin{array}{l}\text { Ability to select and discriminate between different tools } \\
\text { and information managers }\end{array}$ & & & & & \\
\hline 17 & $\begin{array}{l}\text { Solving learning problems and dealing with diversity using } \\
\text { ICT }\end{array}$ & & & & & \\
\hline 18 & $\begin{array}{l}\text { Understanding of the importance of digital competences } \\
\text { for future trainers }\end{array}$ & & & & & \\
\hline 19 & $\begin{array}{l}\text { Ability to use educational tools in the cloud and to create } \\
\text { an interactive learning environment for learners }\end{array}$ & & & & & \\
\hline 20 & $\begin{array}{l}\text { Ability to work in personal networks and cloud learning } \\
\text { environments }\end{array}$ & & & & & \\
\hline 21 & $\begin{array}{l}\text { Teaching role as a guide, mediator and learner in the } \\
\text { teaching-learning process }\end{array}$ & & & & & \\
\hline 22 & $\begin{array}{l}\text { Handling and use of ICT in management process and } \\
\text { organization of research teaching tasks }\end{array}$ & & & & & \\
\hline
\end{tabular}


Appendix 4: Questionnaire for the variable, attitude towards ICT in higher education.

\begin{tabular}{|c|c|c|c|c|c|c|}
\hline \multicolumn{2}{|r|}{$\begin{array}{c}\text { Digital competences of Ecuadorian tourism teaching staff during } \\
\text { the cycle A-2021 }\end{array}$} & \multicolumn{5}{|c|}{ Research } \\
\hline \multicolumn{7}{|c|}{$\begin{array}{l}\text { Instructions: Please respond to all items. Check with an X the box you consider best indicating } \\
\text { the degree to which you identify with each item. } \\
\text { Option } 1 \text { (null), option } 2 \text { (low), option 3(medium), option 4(high), option 5(very high). }\end{array}$} \\
\hline \multicolumn{7}{|c|}{ Date: } \\
\hline \multicolumn{2}{|c|}{ Gender: } & \multicolumn{5}{|c|}{ Options } \\
\hline $\mathrm{N}^{\circ}$ & Variable 4, Attitude towards ICT in higher education & 1 & 2 & 3 & 4 & 5 \\
\hline 1 & $\begin{array}{l}\text { Virtual learning environments provide a better teaching and } \\
\text { learning process. }\end{array}$ & & & & & \\
\hline 2 & $\begin{array}{l}\text { ICT renewal and updating are essential in the information } \\
\text { society. }\end{array}$ & & & & & \\
\hline 3 & $\begin{array}{l}\text { ICT offers greater flexibility and enriches the teaching and } \\
\text { learning process. }\end{array}$ & & & & & \\
\hline 4 & $\begin{array}{l}\text { ICTs promote collaborative networking, establishing a } \\
\text { network of contacts with experts and professionals. }\end{array}$ & & & & & \\
\hline 5 & ICT provides learning beyond time and space. & & & & & \\
\hline 6 & $\begin{array}{l}\text { ICT allows students' creativity and imagination to be } \\
\text { fostered, in order to carry out innovations in their future } \\
\text { teaching work. }\end{array}$ & & & & & \\
\hline 7 & $\begin{array}{l}\text { ICT encourages collaborative networking, establishing a } \\
\text { network of contacts with experts and professionals. }\end{array}$ & & & & & \\
\hline 8 & $\begin{array}{l}\text { The use of mobile devices encourages the implementation of } \\
\text { emerging technologies. }\end{array}$ & & & & & \\
\hline 9 & $\begin{array}{l}\text { Application of open-source resources facilitates work for } \\
\text { teachers and students }\end{array}$ & & & & & \\
\hline 10 & $\begin{array}{l}\text { ICT improves the quality of higher education but does not } \\
\text { solve the problems arising in society }\end{array}$ & & & & & \\
\hline 11 & $\begin{array}{l}\text { The use of ICT in teaching methodology increases student } \\
\text { motivation. }\end{array}$ & & & & & \\
\hline 12 & $\begin{array}{l}\text { ICT training offered is sufficient for teachers' professional } \\
\text { development. }\end{array}$ & & & & & \\
\hline 13 & ICT has limitations due to technical difficulties & & & & & \\
\hline 14 & $\begin{array}{l}\text { Emerging technologies such as Big Data, Augmented } \\
\text { Reality, Analytical Learning favour virtual learning } \\
\text { environments }\end{array}$ & & & & & \\
\hline 15 & $\begin{array}{l}\text { Virtual classrooms do not exploit their potential for } \\
\text { university teaching. }\end{array}$ & & & & & \\
\hline 16 & $\begin{array}{l}\text { ICT represents an investment of time that is considered } \\
\text { wasted by university teaching staff. }\end{array}$ & & & & & \\
\hline
\end{tabular}

